\title{
nature
}

\section{The complex realities of sharing genetic assets}

Debates on bioprospecting tend to be dominated by historical distrust and visions of new riches. Companies and countries alike need to recognize each other's needs, but remain realistic about the issues at stake.

$\mathrm{B}$ ioprospecting, gene-hunting, biopiracy: the terms used to describe the search for natural products of potential value to industry, particularly in the pharmaceutical and agri-business fields, reflect the spectrum of emotions that the practice generates.

Parts of this spectrum will be on display next month, when signatories to the UN Convention on Biodiversity, signed at the Earth Summit in Rio de Janeiro in 1992, hold their fourth meeting at Bratislava in Slovakia. Unsurprisingly, given its origins in the environmentalist concerns of the 1980s, the convention embodies sympathy for the argument that one of the biggest threats to environmental conservation is unconsidered rapaciousness by the private sector. Indeed, its direct challenge to free-market economics - expressed, in particular, through its acknowledgement of governments' sovereign rights over their natural resources - is a significant reason why the convention has not yet been ratified by the US Senate.

A different palette of the same emotions will be on display in 1999 , when representatives of the world's economic ministries meet to discuss revisions to the so-called agreement on Trade Related Aspects of Intellectual Property (TRIPs), part of the negotiations that led to the setting up of the World Trade Organization in 1995. Here the assumptions are very different, namely that excessive government control on resources is to be avoided as an obstacle to economic growth. And such obstacles include the very constraints on the ability of individuals to negotiate market prices of biological resources that the biodiversity convention would allow.

As the Briefing in this issue demonstrates (see pages 535-540), current debates about bioprospecting are considerably more complex than just a confrontation over economic philosophies. There are, for example, widely differing views of the potential value of the assets at stake. Those who perceive a rich seam of gold ready to be mined seem likely to be disappointed. The pickings obtained so far have proved relatively meagre, while the increasing ability of combinatorial chemistry to provide an alternative and considerably more convenient route to novel molecules will only skew the ratio of costs to benefits still further against bioprospecting.

\section{Nuggets}

The nuggets to be found most probably reside in the genetic sequences of plants. Unpublished research at the Science Policy Research Unit (SPRU) at the University of Sussex, England, underlines the importance that industry is already attaching to intellectual property rights on plant DNA sequences. This has revealed a predictably high number of patents filed on major crops such as maize. Rather less predictable is the wide range of patents for DNA sequences already applied for on crops in developing countries that include coconut, the moth bean, nutmeg, coriander, castor bean and cocoa.

The SPRU researchers suggest that the rate of patents filed for plant DNA will rise rapidly over the next 10 to 15 years, as functional analysis of plant genomes creates unprecedented opportunities for crop improvement. Such developments can only increase sensitivi- ties about questions of ownership, and in particular about the meaning of 'national sovereignty' over resources that is enshrined in the biodiversity convention. Similar questions will inevitably arise as the genomic sequencing of substances used in traditional herbal remedies reveals knowledge about their mode of functioning. Should the commercial benefit obtained from this knowledge accrue to those who discovered an active ingredient through a long process of trial and error? Or to the biotechnology company able to identify — and inprove on - this key ingredient in precise scientific terms?

\section{Dangers}

Those who argue in favour of the first approach clearly hold the higher moral ground. Inspired by the successful battles by indigenous communities worldwide for compensation for the expropriation of their lands (and the mineral rights that went with them), such individuals and groups make an appealing case in favour of a socially equitable solution to the distribution of benefits. The danger, their critics point out, is when one man's equity becomes another man's barrier to efficient trade; protectionism is never far below the surface of the arguments of those who complain of exploitation by outsiders.

But there are dangers on the other side too. The strict application of patent laws which, by their nature, tend to favour the most scientifically advanced and innovative economies, place at a significant disadvantage those lacking such resources and skills. The TRIPs agreement would work well if scientific and technical skills were better distributed around the globe; it certainly provides an incentive to countries to develop such skills in order to become effective players in the global economy. But, if left unmodified on the questions of indigenous knowledge and community rights - two concepts without status in free-market economics - it risks enhancing social disparities and thereby fostering social conflict.

There are no easy routes to a resolution. But flexibility and negotiation are the watchwords. For example, companies could agree to buy exploration licences and reach agreement on profit sharing, on the understanding that the benefits to the country concerned should take the form of a direct contribution to its ability to analyse scientifically and make use of its biological resources. Some companies, ranging from the giant Merck to the small California-based Shaman Pharmaceuticals, are already experimenting in this direction. So too are projects such as the International Cooperative Biodiversity Group (ICBG), an expanding network of bioprospecting projects.

The science of genomics may be low on the priorities in some developing countries, while, given current tight research budgets, some companies are unlikely voluntarily to deliver technical assistance windfalls. In the long run, however, only solutions crafted on mutualities of interest - perhaps in the form of corporate support for an international initiative to promote biotechnology in developing countries, modelled on projects such as the ICBG and the International Centre for Genetic Engineering and Biotechnology - can overcome the mistrust and suspicion that dogs the current debate. 